\title{
COMPARATIVE EFFICACY OF DIFFERENT MULCHING MATERIALS TO ENHANCE GROWTH AND DEVELOPMENT AND TO CONTROL WEED INFESTATION IN COTTON CROP
} Abid Hussain Khoso ${ }^{1}$, Mahmooda Buriro ${ }^{*}$, Bakht-un-Nisa Mangan ${ }^{1}$, Naimatullah Laghari ${ }^{1}$,
Muharam Ali Qambrani ${ }^{1}$, Allah Ditta ${ }^{2}$, Muhammad Saeed ${ }^{3}$, Taufiq Nawaz ${ }^{4}$

DOI: https://doi.org/10.28941/pjwsr.v27i4.963

\begin{abstract}
The present study was based on the hypothesis that mulching materials can directly control weeds and indirectly regulate crop growth and development by improving soil fertility. An experiment was conducted to evaluate the "Comparative efficacy of different mulching materials to enhance growth and development and to control weed infestation in cotton" at Student's Experimental Farm, Department of Agronomy, Sindh Agriculture University Tandojam Sindh-Pakistan, during Kharif season, 2016, in triplicate with randomized complete block design (RCBD). The net plot size was $4 \mathrm{~m} \times 3 \mathrm{~m}\left(12 \mathrm{~m}^{-2}\right)$. There were three cotton varieties (Haridost, Shahbaz, and Sind-1), three mulching materials (wheat straw, sunflower, and banana leaves, each applied at $12 \mathrm{t} \mathrm{ha}^{-1}$ ), and a control without any mulching treatment. The study revealed that the maximum sympodial branches plant ${ }^{-1}$ (27.93), opened bolls plant ${ }^{-1}$ (47.53), weight of seed cotton plant $^{-1}(124.55 \mathrm{~g})$, seed index $(8.73 \mathrm{~g})$, seed cotton yield $\left(5394.4 \mathrm{~kg} \mathrm{ha}^{-1}\right)$, staple length $(30.33 \mathrm{~mm})$, ginning out-turn percentage $(37.96 \%)$ and oil contents $(22.45 \%)$ were recorded in Sindh-1 with banana leaves as mulching material. The same treatment caused the maximum leaf area $\left(136.56 \mathrm{~cm}^{-2}\right)$, and leaf area index $(4.92 \mathrm{~cm})$ in Haridost. The minimum weed density $\left(55.00 \mathrm{~m}^{-2}\right)$, weed fresh $\left(293.6 \mathrm{~g} \mathrm{~m}^{-2}\right)$ and dry biomass $\left(122.52 \mathrm{~g} \mathrm{~m}^{-2}\right)$ with maximum weed control $(81 \%)$ was recorded with banana leaves as mulching material in Sindh-1. It can be concluded that mulching with banana leaves at $12 \mathrm{t} \mathrm{ha}^{-1}$ significantly reduced the weeds infestation, resulting in enhanced growth, yield, and physiological parameters of the cotton crop.
\end{abstract}

Keywords: Cotton; Growth; Mulching; Weeds

Citation: Khoso, A.H.; M. Buriro; B.U. Nisa; Mangan; N. Laghari; M.A. Qambrani; A. Ditta; M. Saeed; T. Nawaz. 2021. Comparative Efficacy of Different Mulching Materials to Enhance Growth and Development and to Control Weed Infestation in Cotton Crop. Pak. J. Weed Sci. Res., 27(4): 475-483.

\footnotetext{
${ }^{1}$ Sindh Agriculture University, Tandojam, Sindh, Pakistan

2Shaheed Benazir Bhutto University, Sheringal, Dir (U), Khyber Pakhtunkhwa, 18000, Pakistan

${ }^{3}$ Department of Weed Science \& Botany, The University of Agriculture, Peshawar.

${ }^{4}$ Department of Food Science and Technology, University of Agriculture Peshawar.

*Corresponding author's email: mahmooda_buriro@yahoo.com
} 


\section{Introduction}

During 2019-20, Pakistan ranks $5^{\text {th }}$ among cotton-producing countries worldwide. Cotton cultivation along the Indus River irrigation scheme over almost three million ha has been known as the country's large source of foreign exchange. In Pakistan, cotton is the $2^{\text {nd }}$ among cultivated crops after wheat, adding $4.1 \%$ values in agriculture and $0.8 \%$ in the national gross domestic product (GOP, 2020). Cotton is primarily cultivated for its fiber; however, cottonseed oil, as an edible vegetable oil plays an important role in the national oil industry by contributing about $66 \%$ share in domestic vegetable oil production (Shuli et al., 2018).

Globally, cotton productivity is significantly affected by various abiotic and biotic factors. Among biotic factors, weeds are among the main biological constraints severely affecting cotton productivity and yield loss due to weeds may incline up to $90 \%$ (Cortés et al., 2010; Usman et al., 2020). Weeds influence cotton both directly and indirectly by reducing yield and quality, increasing output cost due to supplementation of more nutrients, water, light, and providing refuge to pathogens, rodents, and nematodes (Bukun, 2004; Hirata et al., 2019). Any specific weed management system could not be effective under all circumstances. The weed population could be reduced by improving weed management practices Jabran (2016).

Mulching is the most suitable physical process to reduce weeds infestation (Khan et al., 2018). The use of crops residues such as stem, leaves, or straw to produce mulch can reduce weeds infestation by preventing germination and development of weeds due to the incorporation of the phytotoxic substances or allelochemicals during the decomposition of plant residues (Putnam et al., 1983; Arentoft et al., 2013; Oliveira Jr et al., 2014; Błażewiczwoźniak et al., 2015; Khan et al., 2018). Sunflower is an important crop for weed control due to its allelopathic impacts. Earlier, 16 allelochemicals (phenolic acids) in eight different sunflower cultivars were detected with a difference in their allelopathic ability. The extracted allelochemicals significantly reduced weed density $(10-87 \%)$, weed biomass (34-81\%), and ultimately improved yield parameters (Alsaadawi et al., 2012). The dry banana leaves applied at 25 tons per hectare have significant potential to supply a significant amount of nutrients when used as mulch or compost (Mehmood et al., 2018).

Many plants have powerful allelopathic effects as revealed through the allelochemicals present in their extracts. Therefore, it would be imperative to exploit and compare the allelopathic potential of crops to reduce weed infestation and yield improvement. The present study was conducted to compare the impact of different mulching materials (wheat straw, sunflower, and banana leaves) on the growth, yield, quality and physiological attributes of cotton varieties and weed parameters.

\section{Materials and Methods \\ Study area}

A field experiment was conducted at the student's experimental farm of the Department of Agronomy, Sindh Agriculture University, Tandojam, during 2016, located at 25025'60" $\mathrm{N}$ and $68^{\circ} 31^{\prime} 60^{\prime \prime} \mathrm{E}$. The mean maximum temperature during the crop period was $38.51{ }^{\circ} \mathrm{C}$ and the minimum temperature was $24.20{ }^{\circ} \mathrm{C}$. The mean relative humidity was $62.55 \%$, and the maximum rainfall of $17.58 \mathrm{~mm}$ was received during the $4^{\text {th }}$ week of August 2016. Before crop sowing, soil analysis $(0-30 \mathrm{~cm})$ regarding various physicochemical properties was done using standard procedures (Klute, 1986; Sparks et al., 1996). As clear from Table 1 , the soil was clay loam in texture, nonsaline, low in organic matter (0.72$0.88 \%)$, low in available phosphorus (3.90-4.94 and $\mathrm{mg} \mathrm{kg}^{-1}$ ) but high in exchangeable potassium (84.58-112.18 $\mathrm{mg} \mathrm{kg}^{-1}$ ).

\section{Experimental design and treatments}

The experiment comprised three cotton varieties i.e. Haridost, Shahbaz, and Sindh-1, and three mulches of wheat straw, sunflower, and banana leaves (Fig. 2). The treatments were arranged in a split-plot randomized complete 
block design (RCBD) in triplicate. The cotton varieties were assigned to the main plots while mulching treatments to the sub-plots. In each main plot, there was control without any mulch treatment. The net plot size in each replicate was $4 \times 3 \mathrm{~m}^{2}$. The mulching materials (wheat straw, sunflower, and banana leaves) collected from the field were applied between the rows at the rate of $12 \mathrm{t} \mathrm{ha}^{-1}$ (Ashrafi et al., 2008).

\section{Cultural Practices}

The field was irrigated before seedbed preparation. After, getting a workable moisture regime, the seedbed was prepared with two plowings followed by planking. Delinted and fumigated cottonseeds (15 kg ha-1) were sown using a manual seed drill at a row-torow distance of 75 and plant-to-plant of $30 \mathrm{~cm}$. Recommended agronomic practices were followed. For fertilizer application, the recommended dose of phosphorus (90 kg ha-1) using diammonium phosphate (DAP) was applied during preparation of seedbed while half of the recommended nitrogen (120 kg ha-1) using urea was applied at the time of sowing. The other half was applied 30 days after sowing. The field was irrigated as per the requirement of the crop. Six irrigations were applied in total during the whole period for the experiment. The first picking was done at the time of $50 \%$ boll opening while the subsequent second and third pickings were carried out when the majority of the bolls were opened.

\section{Growth, yield, and physiological parameters}

The data regarding various agronomic and physiological parameters of cotton and weed control parameters were recorded. Five plants from each plot were randomly selected for plant height, and measuring tape was used. Sympodial branches bearing direct buds and fruits were counted from the five plants from each plot and the mean was calculated. The number of opened and un-opened bolls plant $^{-1}$ was done by counting all opened bolls from five plants from each plot and means were calculated. For the weight of seed cotton boll-1 $(\mathrm{g})$, seed cotton of 20 bolls from each plot was picked, weighed, and then seed cotton boll $^{-1}$ was calculated. Similarly, seed cotton from five plants was collected from each treatment and weighed by electronic weight balance, and the mean was calculated for the weight of seed cotton per plant $(\mathrm{g})$. Similarly, seed cotton yield plot $^{-1}(\mathrm{~kg})$ and then per hectare was calculated by the following formula:

$$
\text { Seed cotton yield }=\frac{\text { Yield } \text { plot }^{-1}}{\text { Area of plot }\left(\mathrm{m}^{2}\right)} \times 1000
$$

After separating the seeds from seed cotton by the ginning process, 100 seeds were taken randomly from each plot and weighed by electronic weight balance $(\mathrm{g})$ for the calculation of seed index.

Lint yield was calculated by multiplying seed cotton yield with ginning out-turn (GOT) percentage. For GOT (\%), seed cotton randomly taken from one square meter from each plot was ginned by an electronic ginner and the weight of lint and seed was weighed separately. The GOT (\%) was calculated by the following formula:

$$
\text { GOT }(\%)=\frac{\text { Lint yield }}{\text { Seed cotton yield }} \times 100
$$

After ginning, a small quantity of lint randomly selected from five plants in each treatment was used for staple length $(\mathrm{mm})$ measurement. For oil contents, ten cottonseeds were selected randomly from each treatment and weighed. The oil was extracted through the Soxhlet apparatus following AOAC (1990).

The leaf area of five randomly selected plants from each plot was measured by using a leaf area meter (LI- 3100C area meter). Leaf area index was calculated using the following formula:

$$
\begin{aligned}
& \text { Leaf area index }(\%)=\frac{\text { Leaf area } \mathrm{cm}^{-1}}{\text { Ground area }} \times 100 \\
& \text { Weed parameters }
\end{aligned}
$$

\section{Weed parameters}

The different weeds species of cotton were observed and their frequency from each plot was recorded randomly to calculate weeds density using the following formula:

$$
\text { Weed density }\left(\mathrm{m}^{-2}\right)
$$

$=\frac{\text { Total no. of weeds for a given treatment }}{\text { Area }\left(\mathrm{m}^{-2}\right)}$

Weed fresh weight $\left(\mathrm{g} \mathrm{m}^{-2}\right)$ was recorded by removing weeds from each plot and immediately weighed. For dry weight, weeds were put into a drying oven at 70 ${ }^{\circ} \mathrm{C}$ for 48 hours or until a constant 
weight was observed. For weed control (\%) under different mulch treatments, the number of weeds in one square meter of each plot was counted and compared with control without any mulch treatment.

\section{Statistical analysis}

The collected data were subjected to analysis of variance (ANOVA) using Statistix ver. 8.1. The difference between treatment means was compared using the least significant difference (LSD) test at $p \leq 0.05$.

\section{Results and Discussion}

\section{Growth and yield parameters}

The statistical analysis of agronomic traits recorded during the experiment showed a statistically significant $(P \leq$ 0.05) interaction effect of different mulching materials and cotton varieties (Table 2). In the case of plant height, the maximum $(133.33 \mathrm{~cm})$ was observed in Haridost with banana leaves as mulching material while that of the minimum $(77.60 \mathrm{~cm})$ was observed in control treatment in Shahbaz without any mulching treatment. However, the maximum sympodial branches plant $^{-1}$ (27.93), opened bolls plant ${ }^{-1}$ (47.53), the weight of seed cotton boll-1 $(2.62 \mathrm{~g})$, and weight of seed cotton plant ${ }^{-1}$ $(124.55 \mathrm{~g})$ was recorded in Sindh-1 with banana leaves as mulching material. These results were similar to the findings of Roy et al. (2006) reported that seed germination and seedling development of various vegetable crops were positively affected by the extract from various plant parts of the banana. The minimum number of sympodial branches plant $^{-1}$ (11.80), opened bolls plant $^{-1}$ (20.36), the weight of seed cotton boll-1 $(2.01 \mathrm{~g})$, and weight of seed cotton plant ${ }^{-1}(40.99 \mathrm{~g})$ was noted in Shahbaz under control treatment without any mulching material. The results further indicated that the maximum number of unopened bolls plant $^{-1}$ (8.03) were observed in the same variety and treatment (no mulching material), followed by (7.53) the same variety with sunflower as mulching material. The minimum number of unopened bolls plant ${ }^{-1}$ (4.15) was noted in Sindh-1 with banana leaves as mulching material. In another study, Nadeem et al. (2013) also stated that enhanced growth, yield, and weed control parameters were observed with the application of mulch in comparison to the control without mulching treatment.

Different mulching materials also showed a statistically significant ( $p \leq$ 0.05 ) effect on yield and parameters of different cotton varieties (Table 3 ). The maximum seed index $(8.73 \mathrm{~g})$, seed cotton yield plot $^{-1}(6.47 \mathrm{~kg})$, seed cotton yield ha-1 $(5394.4 \mathrm{~kg})$, staple length $(30.33 \mathrm{~mm})$, GOT percentage $(37.96 \%)$ and oil contents $(22.45 \%)$ were recorded with the application of banana leaves as mulching material in Sindh-1. Van Asten et al. (2004) also reported that dry banana leaves can serve as an important material to enhance soil fertility and ultimately improve crop yield with reduced weeds. Mahmood et al. (2008), also suggested that soil mulching with crop wastes/residues or synthetic ones improves soil water preservation by decreasing soil evaporation and increasing crop yield. The minimum seed index $(6.30 \mathrm{~g})$, seed cotton yield plot ${ }^{-1}(2.13 \mathrm{~kg})$, seed cotton yield ha ${ }^{-1}(1775 \mathrm{~kg})$, staple length (25.66 mm), GOT (32.36\%), and oil contents $(17.11 \%)$ were noted in Shahbaz under control treatment without any mulching material.

\section{Physiological and weed parameters}

The interactive effect between different mulching materials and cotton varieties on physiological parameters was statistically significant $(p \leq 0.05)$. The maximum leaf area $\left(136.56 \mathrm{~cm}^{-2}\right)$, and leaf area index $(4.92 \mathrm{~cm})$ were recorded in Haridost with banana leaves as mulching material, followed by leaf area $\left(132.60 \mathrm{~cm}^{-2}\right)$, and leaf area index $(4.72$ $\mathrm{cm}$ ) noted in Sindh-1 with banana leaves as mulching material. The minimum leaf area $\left(93.70 \mathrm{~cm}^{-2}\right)$, and leaf area index $(2.36 \mathrm{~cm})$ were noted in Shahbaz under control treatment without mulching material.

As clear from Table 4, the highest weed density (195.67, 191.33, and $186.33 \mathrm{~m}^{-}$ $\left.{ }^{2}\right)$ was observed in Shahbaz, Haridost, and Sindh-1 under control (weedy check). The main species of different weeds observed in the field included narrow leaf weeds (Brachiaria reptans L., Cynodon dactylon Pers., Cyperus iria 
L., Desmostachya bipinnata L., Echinochloa colonum L., and Sorghum halepense (L.) Pers.), broadleaf weeds (Convolvulus arvensis L., Corchorus depressus L., Digera arvensis Forssk., and Trianthema portulacastrum L.) and Sedge grass (Eleusine indica L. Gaertn.). Similarly, the maximum weed fresh $\left(1138.4 \mathrm{~g} \mathrm{~m}^{-}\right.$ ${ }^{2}$ ), and dry biomass (472.74 $\mathrm{g} \mathrm{m}^{-2}$ ) was recorded under control treatment (weedy check) in Shahbaz, followed by weed density $\left(85.33 \mathrm{~m}^{-2}\right.$ ) was observed in the same variety under sunflower as mulching material, while weed fresh, and dry biomasses were recorded in Haridost under weedy check plots 1027.0 and $442.75 \mathrm{~g} \mathrm{~m}^{-2}$, respectively. The minimum weed density $\left(55.00 \mathrm{~m}^{-2}\right)$, weed fresh $\left(293.6 \mathrm{~g} \mathrm{~m}^{-2}\right)$ and dry biomass (122.52 $\mathrm{g} \mathrm{m}^{-2}$ ) was recorded with banana leaves as mulching material in Sindh-1. The maximum weed control $(81 \%)$ was recorded with banana leaves as mulching material in Sindh-1, followed by weed control $(77.82 \%)$ in Haridost with banana leaves as mulching material. The maximum number of weeds were observed in all tested varieties under control treatment (weedy check). These findings agree with those Essien et al., (2009); NejatzadehBarandozi, (2020) who observed that the frequency of weeds was higher in control treatment without mulch material compared to the plots with mulches and suggested that mulches can suppress weeds under field conditions.

Table 1: Basic physicochemical properties of soil at different depths

\begin{tabular}{|c|c|c|c|c|c|c|c|}
\hline $\begin{array}{l}\text { Depth } \\
\text { (cm) }\end{array}$ & Soil texture & pH & $E C\left(d S ~^{-1}\right)$ & $\begin{array}{l}\text { OM } \\
(\%)\end{array}$ & $\begin{array}{c}N \\
(\%)\end{array}$ & $P\left(\mathrm{mg} \mathrm{kg}^{-1}\right)$ & $K\left(\mathrm{mg} \mathrm{kg}^{-1}\right)$ \\
\hline $0-15$ & Clay loam & 7.5 & 0.80 & 0.88 & 0.073 & 4.94 & \\
\hline $15-30$ & Clay loam & 7.6 & 0.72 & 0.72 & 0.057 & 3.90 & $\begin{array}{l}112.18 \\
84.58\end{array}$ \\
\hline
\end{tabular}

Table 2: Impact of different mulching materials on growth parameters of different cotton

\begin{tabular}{|c|c|c|c|c|c|c|c|}
\hline \multirow[b]{2}{*}{ Varieties } & \multirow[b]{2}{*}{$\begin{array}{l}\text { Mulching } \\
\text { materials }\end{array}$} & \multicolumn{6}{|c|}{ Agronomic traits } \\
\hline & & $\begin{array}{l}\text { Plant } \\
\text { height } \\
(\mathbf{c m})\end{array}$ & $\begin{array}{c}\text { Sympodial } \\
\text { branches }^{\text {plant }}{ }^{-1}\end{array}$ & \begin{tabular}{|c|} 
Opened \\
bolls \\
plant $^{-1}$
\end{tabular} & $\begin{array}{l}\text { Unopened } \\
\text { bolls } \\
\text { plant }^{-1}\end{array}$ & $\begin{array}{c}\text { Wt. of } \\
\text { seed } \\
\text { cotton } \\
\text { boll-1 }^{-1} \\
(\mathrm{~g})\end{array}$ & $\begin{array}{l}\text { Wt. of } \\
\text { seed } \\
\text { cotton } \\
\text { plant } \\
(\mathbf{g})\end{array}$ \\
\hline \multirow{4}{*}{ Hari Dost } & Weedy check & $84.93 i$ & $13.46 \mathrm{~h}$ & $26.40 i$ & $7.40 \mathrm{bc}$ & $2.12 \mathrm{ij}$ & $55.96 i$ \\
\hline & \multirow{3}{*}{$\begin{array}{l}\text { Wheat straw } \\
\text { Sunflower } \\
\text { Banana leaves }\end{array}$} & $127.33 \mathrm{c}$ & $20.06 \mathrm{de}$ & $35.44 \mathrm{~d}$ & $5.70 \mathrm{~g}$ & $2.33 \mathrm{~d}$ & $82.69 \mathrm{e}$ \\
\hline & & $123.93 \mathrm{~d}$ & $18.46 \mathrm{f}$ & $30.09 \mathrm{f}$ & $7.20 \mathrm{~d}$ & $2.22 \mathrm{fg}$ & $66.91 \mathrm{~g}$ \\
\hline & & $133.33 a$ & $24.93 \mathrm{~b}$ & $44.60 \mathrm{~b}$ & $4.54 i$ & $2.55 \mathrm{~b}$ & $\begin{array}{l}113.8 \\
b\end{array}$ \\
\hline \multirow{4}{*}{ Shahbaz } & Weedy check & $77.60 \mathrm{k}$ & 118 & $20.36 j$ & $8.03 \mathrm{a}$ & $2.01 \mathrm{k}$ & $40.99 j$ \\
\hline & Whe & 117. & & 28 & & $2.16 \mathrm{hi}$ & $62.39 \mathrm{~h}$ \\
\hline & Sunflow & $112.87 \mathrm{~h}$ & 14.2 & $26.52 \mathrm{i}$ & $7.53 \mathrm{~b}$ & $2.08 \mathrm{j}$ & $55.17 \mathrm{i}$ \\
\hline & Banana leaves & $121.33 \mathrm{e}$ & & & 5.71 & $2.27 \mathrm{e}$ & $88.84 \mathrm{~d}$ \\
\hline \multirow{3}{*}{ Sindh-1 } & Weedy check & 82. & 13 & $\mathrm{~h}$ & $7.31 \mathrm{~cd}$ & $\begin{array}{l}2.18 \\
\mathrm{gh}\end{array}$ & $61.46 \mathrm{~h}$ \\
\hline & Wheat straw & $124.67 \mathrm{~d}$ & 20.73 de & $38.64 \mathrm{c}$ & $5.48 \mathrm{~h}$ & $2.40 \mathrm{c}$ & $93.38 \mathrm{c}$ \\
\hline & Sunflower & $120.33 \mathrm{f}$ & & & $7.13 \mathrm{de}$ & 2.24 ef & $\begin{array}{l}78.01 \mathrm{f} \\
124.55 \mathrm{a}\end{array}$ \\
\hline LSD at 5\% & $\mathrm{Ba}$ & $\begin{array}{l}130.0 \\
0.74\end{array}$ & 0.75 & $\begin{array}{l}47.53 a \\
\mathbf{0 . 5 4}\end{array}$ & $\begin{array}{l}4.15 j \\
\mathbf{0 . 1 5}\end{array}$ & $\begin{array}{l}2.62 \mathrm{a} \\
0.04\end{array}$ & $\begin{array}{l}124.55 a \\
\mathbf{2 . 1 7}\end{array}$ \\
\hline
\end{tabular}


480 Abid Hussain Khoso, Mahmooda Buriro et al. Comparative Efficacy of Different ....

Table 3: Impact of different mulching materials on yield parameters of different cotton varieties

\begin{tabular}{|c|c|c|c|c|c|c|c|}
\hline \multirow[b]{2}{*}{ Varieties } & \multirow[b]{2}{*}{$\begin{array}{l}\text { Mulching } \\
\text { materials }\end{array}$} & \multicolumn{6}{|c|}{ Yield parameters } \\
\hline & & $\begin{array}{c}\text { Seed } \\
\text { index } \\
(100 \\
\text { seed } \\
\text { weight } \\
(\mathrm{g}) \\
\end{array}$ & $\begin{array}{c}\text { Seed } \\
\text { cotton } \\
\text { yield } \\
\text { plot }^{-1} \\
(\mathbf{k g})\end{array}$ & $\begin{array}{c}\text { Seed } \\
\text { cotton } \\
\text { yield ha-1 } \\
(\mathbf{k g})\end{array}$ & $\begin{array}{c}\text { Staple } \\
\text { length } \\
(\mathbf{m m})\end{array}$ & $\begin{array}{l}\text { Ginning } \\
\text { out-turn } \\
\text { (GOT \%) }\end{array}$ & $\begin{array}{c}\text { Oil } \\
\text { content } \\
(\%)\end{array}$ \\
\hline \multirow{4}{*}{ Hari Dost } & $\begin{array}{l}\text { Weedy } \\
\text { check }\end{array}$ & 7.79 de & $2.91 \mathrm{i}$ & $2425.0 \mathrm{i}$ & 26.33 ef & $33.77 \mathrm{de}$ & $17.90 \mathrm{~h}$ \\
\hline & $\begin{array}{l}\text { Wheat } \\
\text { straw }\end{array}$ & $8.17 \mathrm{c}$ & $4.29 \mathrm{e}$ & $3580.6 \mathrm{e}$ & $28.66 \mathrm{c}$ & $34.07 \mathrm{de}$ & $20.40 c$ \\
\hline & Sunflower & $7.85 \mathrm{~d}$ & $3.47 \mathrm{~g}$ & $2894.4 \mathrm{~g}$ & $27.00 \mathrm{de}$ & $33.79 \mathrm{de}$ & $19.44 \mathrm{e}$ \\
\hline & $\begin{array}{l}\text { Banana } \\
\text { leaves }\end{array}$ & $8.30 \mathrm{~b}$ & $5.92 \mathrm{~b}$ & $4933.3 \mathrm{~b}$ & $30.00 \mathrm{~b}$ & $34.56 \mathrm{~d}$ & $22.44 a$ \\
\hline \multirow{4}{*}{ Shahbaz } & $\begin{array}{l}\text { Weedy } \\
\text { check }\end{array}$ & $6.30 \mathrm{~g}$ & $2.13 \mathrm{j}$ & $1775.0 \mathrm{j}$ & $25.66 \mathrm{f}$ & $32.36 \mathrm{f}$ & $17.11 \mathrm{i}$ \\
\hline & $\begin{array}{l}\text { Wheat } \\
\text { straw }\end{array}$ & $7.76 \mathrm{e}$ & $3.24 \mathrm{~h}$ & $2699.8 \mathrm{~h}$ & $28.33 \mathrm{c}$ & $33.90 \mathrm{de}$ & $19.87 \mathrm{~d}$ \\
\hline & Sunflower & $6.79 \mathrm{f}$ & $2.86 \mathrm{i}$ & 2386.11 & $26.33 d$ & 33.35 ef & $18.42 \mathrm{e}$ \\
\hline & $\begin{array}{l}\text { Banana } \\
\text { leaves }\end{array}$ & $8.28 \mathrm{~b}$ & $4.61 \mathrm{~d}$ & $3844.4 \mathrm{~d}$ & $29.66 \mathrm{ab}$ & $34.00 \mathrm{de}$ & $20.31 \mathrm{c}$ \\
\hline \multirow{4}{*}{ Sindh-1 } & $\begin{array}{l}\text { Weedy } \\
\text { check }\end{array}$ & $7.82 \mathrm{de}$ & $3.19 \mathrm{~h}$ & $2658.3 \mathrm{~h}$ & $26.66 \mathrm{de}$ & $35.86 \mathrm{c}$ & $18.92 \mathrm{f}$ \\
\hline & $\begin{array}{l}\text { Wheat } \\
\text { straw }\end{array}$ & $8.34 \mathrm{~b}$ & $4.85 \mathrm{c}$ & $4022.2 \mathrm{c}$ & $29.00 \mathrm{bc}$ & $37.48 \mathrm{ab}$ & $20.94 b$ \\
\hline & Sunflower & $8.10 \mathrm{c}$ & $4.04 \mathrm{f}$ & $3372.2 \mathrm{f}$ & $27.33 \mathrm{~d}$ & $36.63 \mathrm{bc}$ & $19.52 \mathrm{e}$ \\
\hline & $\begin{array}{l}\text { Banana } \\
\text { leaves }\end{array}$ & $8.73 \mathrm{a}$ & $6.47 \mathrm{a}$ & $5394.4 \mathrm{a}$ & $30.33 \mathrm{a}$ & $37.96 \mathrm{a}$ & $22.45 a$ \\
\hline LSD at $\mathbf{5 \%}$ & - & 0.07 & 0.11 & 94.49 & 0.95 & 1.13 & 0.12 \\
\hline
\end{tabular}

Table 4: Impact of different mulching materials on physiological parameters of cotton varieties and weed traits

\begin{tabular}{|c|c|c|c|c|c|c|c|}
\hline \multirow[b]{2}{*}{ Varieties } & \multirow[b]{2}{*}{$\begin{array}{l}\text { Mulching } \\
\text { materials }\end{array}$} & \multicolumn{2}{|c|}{$\begin{array}{c}\text { Crop physiological } \\
\text { traits }\end{array}$} & \multicolumn{4}{|c|}{ Weed traits } \\
\hline & & $\begin{array}{c}\text { Leaf area } \\
\left(\mathrm{cm}^{2}\right)\end{array}$ & $\begin{array}{l}\text { Leaf area } \\
\text { index } \\
(\mathrm{cm})\end{array}$ & $\begin{array}{c}\text { Weed } \\
\text { density } \\
\left(\mathrm{m}^{-2}\right)\end{array}$ & $\begin{array}{c}\text { Weed } \\
\text { fresh } \\
\text { biomass } \\
\left(\mathrm{g} \mathrm{m}^{-2}\right)\end{array}$ & $\begin{array}{c}\text { Weed } \\
\text { dry } \\
\text { biomass } \\
\left(\mathrm{g} \mathrm{m}^{-2}\right)\end{array}$ & $\begin{array}{c}\text { Weed } \\
\text { control } \\
(\%)\end{array}$ \\
\hline \multirow{4}{*}{ Hari Dost } & Weedy check & $99.24 i$ & $2.85 \mathrm{~g}$ & $191.33 \mathrm{a}$ & $1027.0 \mathrm{~b}$ & $442.75 b$ & $0.00 \mathrm{~g}$ \\
\hline & Wheat straw & $128.97 \mathrm{c}$ & $4.42 \mathrm{c}$ & $63.33 \mathrm{de}$ & $325.1 \mathrm{~g}$ & $141.44 \mathrm{~h}$ & $70.58 c$ \\
\hline & Sunflower & $116.37 \mathrm{f}$ & $3.13 \mathrm{f}$ & $78.67 \mathrm{bc}$ & $416.6 \mathrm{e}$ & $180.43 \mathrm{e}$ & $62.73 \mathrm{e}$ \\
\hline & $\begin{array}{l}\text { Banana } \\
\text { leaves }\end{array}$ & $136.56 \mathrm{a}$ & $4.92 \mathrm{a}$ & $57.00 \mathrm{e}$ & $309.9 \mathrm{gh}$ & $133.01 \mathrm{i}$ & $77.82 \mathrm{~b}$ \\
\hline \multirow{4}{*}{ Shahbaz } & Weedy check & $93.70 \mathrm{k}$ & $2.36 \mathrm{~h}$ & $195.67 \mathrm{a}$ & $1138.4 \mathrm{a}$ & $472.74 \mathrm{a}$ & $0.00 \mathrm{~g}$ \\
\hline & Wheat straw & $123.44 \mathrm{e}$ & $4.16 \mathrm{e}$ & $71.33 \mathrm{~cd}$ & $421 \mathrm{de}$ & $174.12 \mathrm{f}$ & $67.75 \mathrm{~d}$ \\
\hline & Sunflower & $112.59 \mathrm{~h}$ & $3.05 \mathrm{f}$ & $85.33 \mathrm{~b}$ & $483.5 d$ & 204.32 d & $58.61 \mathrm{f}$ \\
\hline & $\begin{array}{l}\text { Banana } \\
\text { leaves }\end{array}$ & $128.79 \mathrm{c}$ & $4.23 \mathrm{de}$ & $60.67 \mathrm{de}$ & $371.6 \mathrm{f}$ & $154.26 \mathrm{~g}$ & $75.84 b$ \\
\hline \multirow{4}{*}{ Sindh-1 } & Weedy check & $95.80 \mathrm{j}$ & $2.79 \mathrm{~g}$ & $186.33 \mathrm{a}$ & $985.5 \mathrm{c}$ & $427.43 c$ & $0.00 \mathrm{~g}$ \\
\hline & Wheat straw & $126.58 d$ & $4.31 \mathrm{~d}$ & $62.33 \mathrm{de}$ & $324.1 \mathrm{~g}$ & $138.34 \mathrm{hi}$ & $71.58 \mathrm{c}$ \\
\hline & Sunflower & $114.92 \mathrm{~g}$ & $3.11 \mathrm{f}$ & $78.00 \mathrm{bc}$ & $416.3 \mathrm{e}$ & $176.73 \mathrm{ef}$ & $64.10 \mathrm{e}$ \\
\hline & $\begin{array}{l}\text { Banana } \\
\text { leaves }\end{array}$ & $132.60 \mathrm{~b}$ & $4.72 \mathrm{~b}$ & $55.00 \mathrm{e}$ & $293.6 \mathrm{~h}$ & $122.52 \mathrm{j}$ & $81.00 \mathrm{a}$ \\
\hline LSD at $5 \%$ & - & 0.36 & 0.10 & 10.85 & 21.64 & 5.72 & 2.53 \\
\hline
\end{tabular}




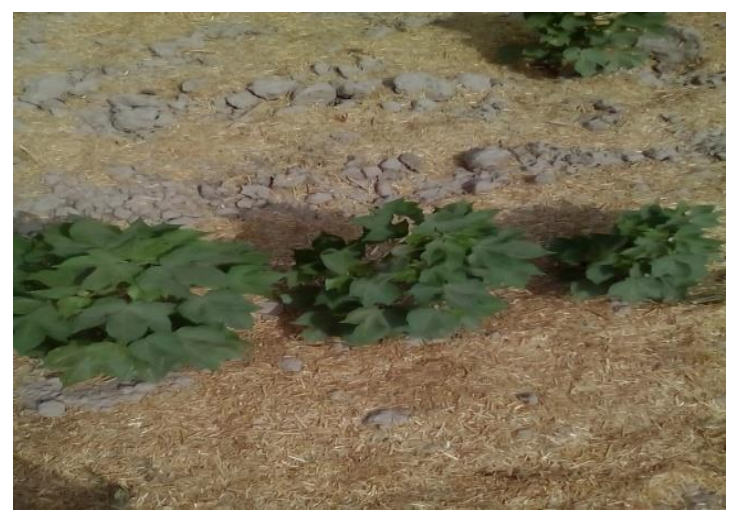

Wheat Straw Mulch

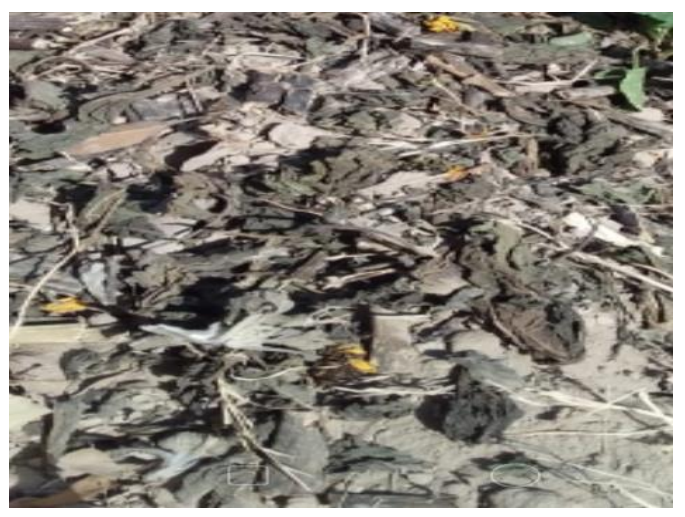

Sunflower whole plant Mulch

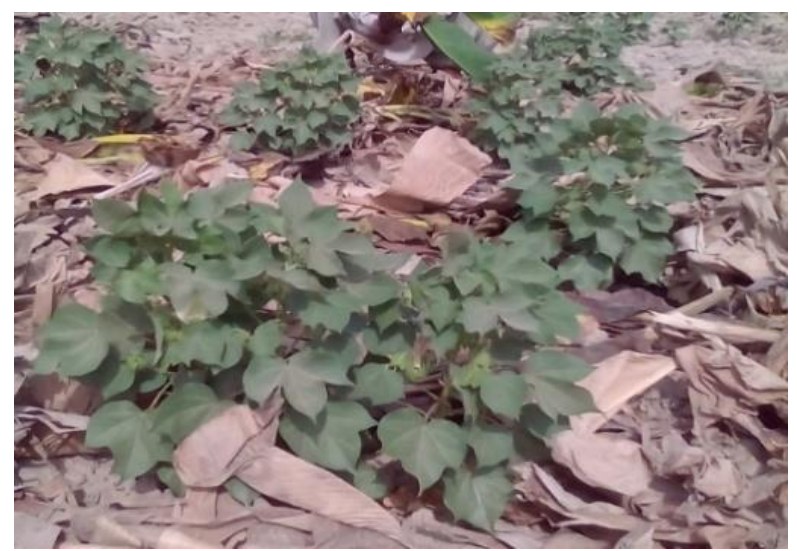

Banana leaves Mulch

Fig. 1: Different types of plants material used for mulching

\section{Conclusions}

It can be concluded that mulching with banana leaves at $12 \mathrm{t} \mathrm{ha}^{-1}$ significantly reduced the weeds infestation, resulting in enhanced growth, yield and physiological parameters of the cotton crop.

\section{Acknowledgment}

This research paper is a part of my Ph.D. thesis, which has been submitted to Sindh Agriculture University, Tandojam, Pakistan.

\section{Author contribution statement}

All authors contributed to the study conception and design. Abid Hussain Khoso, Mahmooda Buriro and Bakht-un-
Nisa Mangan performed experimentation and analysis. Abid Hussain Khoso, Naimatullah Laghari, Muharam Ali Qambrani, Allah Ditta and Muhammad Saeed wrote first draft of the manuscript. All authors gave their feedback and input during the write up, experimentation, analysis, data validation and proofread of the present research work. Mahmooda Buriro and Bakht-un-Nisa Mangan supervised and did the final proofreading of the article.

\section{Conflict of interest}

The authors declare that they have no conflict of interest. 


\section{References}

Alsaadawi, I.S., A.K. Sarbout, Al- and L.M. Shamma. 2012. Differential allelopathic potential of sunflower (Helianthus annuus L.) genotypes on weeds and wheat (Triticum aestivum L.) crop. Arch. Agron. Soil Sci., 58(10): 1139-1148.

AOAC. Methods of the Association of Official Analytical Chemists (15 $5^{\text {th }}$ ed.), AOAC, Arlington, VA, USA 1990, Method No. 920.85. 1990; p. 780 .

Arentoft, B.W., A. Ali, Streibig and J.C., Andreasen, C. 2013.A new method to evaluate the weed-suppressing effect of mulches: a comparison between spruce bark and cocoa husk mulches. Weed Res., 53(3): 169-175.

Ashrafi, Z.Y., A. Rahnavard, S. Sadeghi, S. Hassan, M. Alizade, and H.R. Mashhadi. 2008. Study of the allelopathic potential of extracts of Azadirachta Indica (Neem). J. Biol. Sci., 8: 57-61.

Błażewicz-Woźniak, M., E. Patkowska, M. Konopiński and D. Wach. 2015. The effect of no-ploughing tillage using cover crops on primary weed infestation of carrot. Acta. Sci. Pol. Hortorum. Cultus., 14(2): 27-40.

Bukun, B. 2004 Critical periods for weed control in cotton in Turkey. Weed Res., 44(5):404-412.

Cortés., J.A., M.A. Mendiola, M. Castejón. 2010. Competencia de abutilon (Abutilon theophrasti M) en algodón (Gossipium hirsutum L). Umbral económico de daño. Span. J Agric Res., 8(2): 391-399.

Essien, B.A., J.B. Essien, J.C. Nwite, K.A. Eke, U.M. Anaele, and J.U. Ogbu. 2009. Effect of organic mulch materials on maize performance and weed growth in the derived savanna of southeastern Nigeria. Nigeria Agric. J., 40(2): 587-605.

GOP (Govt. of Pakistan). 2020. Pakistan Economic Survey, Economic Adviser's Wing, Finance Division, Government of Pakistan, Islamabad. pp: 17-41.

Hirata, A.C.S., E.K. Hirata, AB. Rós, N. Narita. 2019. Cauliflower cultivars associated with Urochloa decumbens straw mulch in integrated weed management. Planta Daninha, 37: e019212770

Jabran, K., Z.A. Cheema, M. Farooq, and M. Hussain. 2010. Lower doses of pendimethalin mixed with allelopathic crop water extracts for weed management in canola (Brassica napus). Int. J. Agric. Biol., 12: 335-340.

Jabran, K. 2016. Weed flora, yield losses and weed control in cotton crop. Julius-Kühn-Archiv., 452: 177182.

Khan, I., M.I. Khan, H. Ullah, M. Haroon and B. Gul. 2018. Assessment of integrated weed management approaches on Asphodelus tenuifolius in chickpea. Planta Daninha, 36: e018179088.

Klute, A. 1986. Methods of Soil Analysis. Part 1. Physical and Mineralogical Methods. American Society of Agronomy, Inc., Madison.

Mahmood, K., A. Khaliq, Z.A. Cheema, M. Arshad. 2013. Allelopathic activity of Pakistani wheat genotypes against wild oat (Avena fatua L.). Pak. J. Agric. Sci., 50(2): 169-176.

Mehmood, T., S.U. Khan, A. Qayyum, A.R. Gurmani, W. Ahmed, M. Liaquat, A. Farid. 2018. Evaluation of organic and inorganic mulching as an integrated weed management strategy in maize under rainfed conditions. Planta Daninha, 36: e018184892.

Nadeem, M.A., M. Idrees, M. Ayub, A. Tanveer and $K$. Mubeen. 2013.Effect of different weed control practices and sowing methods on weeds and yield of cotton. Pak. J. Bot., 45(4): 13211328.

Nejatzadeh-Barandozi, F. 2020. Effects of different levels of mulch and irrigation on growth traits and essential oil content of basil. Ital. J. Agron., 15: 1247.

Oliveira, Jr .R.S., F.A. Rios, J. Constantin, E.L. Ishii-Iwamoto, A. Gemelli and P.E. Martini. 2014. Grass straw mulching to suppress the emergence and early growth 
of weeds. Planta Daninha, 32(1): 11-17.

Roy, S., M. Asaduzzaman, M.H.R. Pramanik, and A.K.M.A. Prodhan. 2006. Effect of banana plant extracts on germination and seedling growth of some vegetable crops. Bangladesh J. Crop Sci., 17(1): 235-242.

Shuli, F., A.H. Jarwar, X. Wang, L. Wang, and Q. Ma. 2018. Overview of cotton in Pakistan and its future prospects. Pak. J. Agric. Res., 31(4): 396.

Silva, G.H. 2020. The biodegradable mulch of recycled paper reduces water consumption and crop coefficient of pak choi. Sci Hortic., 267: 109315.

Sparks, D.L., A.L. Page, M.E. Sumner, M.A. Tabatabai, and P.A. Helmke. 1996. Methods of Soil Analysis Part 3. Chemical Methods. Soil Science Society of America, Madison, USA.

Usman, M., G. Murtaza, A. Ditta, T. Bakht, M. Asif, M. Nadir and S. Nawaz. 2020. Distribution pattern of weeds in the wheat crop grown in district Khanewal, Punjab, Pakistan. Pak. J. Weed Sci. Res., 26(1): 47-59.

Van Asten, P.J.A., C.S. Gold, SH. Okech, S.V. Gaidashova, W.K. Tushemereirwe and D. De Waele. 2004. Soil quality problems in East African banana systems and their relation with other yield loss factors. InfoMusa, 13(2): 20-25. 